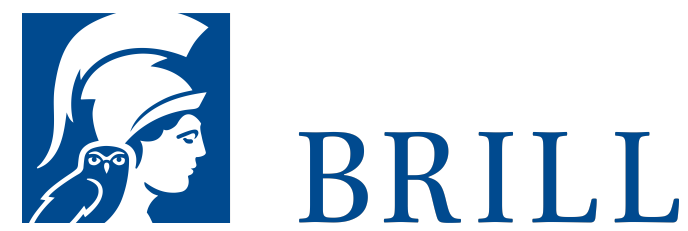

\title{
Die Sprache des verschuldeten Menschen
}

Literarische Umgangsformen mit Schulden, Schuld und Schuldigkeit

Author: Daniel Cuonz

Seit der Finanzkrise von 2008 gibt es eine öffentliche Diskussion über die Bedeutung der Schulden für das menschliche Leben und Zusammenleben. Der verschuldete Mensch lebt im Spannungsfeld von ökonomischen Schulden und moralischer Schuld. Im Lauf der Zeit und unter dem Druck der Verhältnisse hat er die verhängnisvolle Lektion gelernt, sich für seine Schulden schuldig zu fühlen. Das hat auch in der Literaturgeschichte Spuren hinterlassen. In Werken von Shakespeare und Lessing, Keller und Flaubert, Nietzsche und Dostojewskij, von Ibsen, Brecht oder Dürrenmatt erhält das Leben in und mit Schulden individuelle Kontur. Mit Blick auf die Möglichkeiten und Grenzen unterschiedlicher literarischer Darstellungsformen zeigen sich Handlungsspielräume, die sich dem verschuldeten Menschen trotz oder gerade wegen der ungesicherten Verhältnisbestimmung von Schulden, Schuld und Schuldigkeit eröffnen.

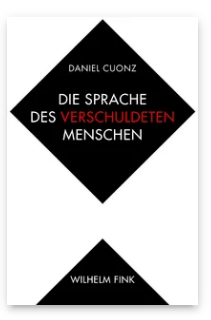

Pages: 342

Seiten

Language:

German

Subjects:

History of

Linguistics \&

Philosophy of

Language,

Languages and

Linguistics

Publisher: Brill |

Fink

E-Book (PDF)

Released online:

O4 Nov 2019

ISBN: 978-3-

8467-6299-8

List price

Paperback

Publication date:

o1 Dec 2017

ISBN: 978-3-

7705-6299-2

List price 
Biographical Note

Daniel Cuonz ist seit 2010 Lehrbeauftragter und seit 2014

Privatdozent an der School of Humanities and Social Sciences der Universität St. Gallen.

For more information see brill.com

Order information: Order online at brill.com +44 330 333 0049 | customerservices@brill.com Submission information: brill.com/authors

Titles published by Brill | Fink, Brill | mentis or Brill | Schöningh: +49(o)71 5413279216 | brill@brocom.de 